\title{
ORGANISED CRIME AS AN ENTREPRENEURIAL ACTIVITY
}

\author{
Costin-Dan DAVID ${ }^{a *}$, Dănuț-Dumitru DUMITRAȘCU ${ }^{b}$ \\ a,b “Lucian Blaga” University of Sibiu, Romania
}

\begin{abstract}
Criminal activity, in the minds of everyday individuals, usually means money, power and influence, but at the same time, it represents business like results and entrepreneurial thinking, and nothing brings in more money than organised crime. We are starting to tackle the idea that organised crime can be seen from an entrepreneurial perspective, while underlining the concepts of organised crime, corruption, and several characteristics of organised crime. At the same time, the paper points out some elements regarding the concept of entrepreneurship and some of its characteristics, while drawing a parallel between the two main ideas of the paper "organised crime" \& "entrepreneurship". In itself, the paper brings to light and tries to bridge the gap in understanding some of the links between entrepreneurship and organised crime. Considering some of the similarities between the entrepreneurial way and the organised crime method of making money, we are also presenting the results of a brief secondary data analysis based on reports, strategies regarding the economic effects of organised crime.
\end{abstract}

KEYWORDS: business, entrepreneurship, illegal activity, organised crime.

\section{INTRODUCTION}

The business of crime is one of the most interesting aspects that can be studied at the time because, seeing the criminal activity as an entrepreneurial activity is a whish of the members of criminal entities since the second half of the $20^{\text {th }}$ Century. One of the most versatile and negative elements of our social environment, the organised crime is very good at adapting to fit their criminal activities. As you probably suspect, the business of organised crime is to make money, and lots of money, and when we talk about organised crime as a business, we usually consider medium and larger criminal entities, rather than the small-time illegal activities. When we consider organised crime, most of us, are rapidly thinking of drug trafficking, money laundering, prostitution, gambling, racketeering etc., illegal activities that have generated huge amounts of money for the members of organised crime and important losses for the governments. Beker (1968, in Scandizo \& Ventura, 2015) argued that crime is an economically important activity or industry, almost totally neglected by economists, probably because its immoral nature is seen somewhat to exclude it from scientific attention.

The current paper underlines the idea the organised crime can be seen as a business by the members of said illegal activity, on one side, we point out the concept of corruption and organised crime, while presenting several characteristics that can help us understand organised crime. Secondly, we present a link between entrepreneurship thinking and organised crime business like thinking, while showing the negative impact of organised crime on the social and economic environment of one's society. At the same we are trying to bridge the gap in understanding some of the links that connect organised crime and the entrepreneurial environment from a theoretical perspective, in order to provide a better understanding of the current literature review status.

\footnotetext{
*Corresponding author. E-mail address: costin.david@ulbsibiu.ro
} 


\section{ORGANISED CRIME - CONCEPT AND CHARACTERISTICS}

Defining corruption and organised crime is a complicated affair, because these two concepts have no clear and universal accepted definitions. Corruption is phenomena that has a destructive effect on the institutional processes and on the trust of the population on said institutions (Volintiru, 2014). From an etymological perspective, the word corruption comes from the Latin word coruptioonis, meaning lack of morality, honour, or duty (Dex, 1958).

In the context of the international law, we can find a synthetic definition of corruption as "acts in which the power of public office is used for personal gain in a manner that contravenes the rules of the game. There are several acts such as money laundering, drug trades, fraud, and black-market operations, don't represent corruption-associated acts in and of themselves because they do not involve the use of public power" (Vogl, 1998, Jain, 2008)

At the same time the UN Manual on anticorruption policies (UN, 2021), defines corruption as "the abuse of public power for a private benefice, to the detriment of the public interest". Transparancy International (2021) defined corruption as "the abusive use of the power intrusted with the purpose of satisfying some personal interests". Therefore, from a conceptual perspective the concept of corruption underlines an abuse of power that is being done while discharging public function specific activities, with the purpose of obtaining a personal gain, directly or indirectly, for oneself or for another individual.

As for organised crime, it is also difficult to define, because the manner in which one defines organised crime and also corruption is strongly linked to the legislation of each country. At present, no other area in the field of criminal justice is as difficult to define, describe, treat from an operational perspective, evaluate, conduct research on and develop policy recommendations as is in the case of organised crime. (Steffensmeier, 1995) Regarding the perception of organized crime and especially when it is difficult to explain in a comprehensive or systematic way this concept, there have always been a large number of efforts to model and understand organized crime, most intervening in the last four decades (Albanese, 2010).

If we choose a somewhat historical approach to the concept of organized crime, it, as it is used today, is essentially an invention of the nineteenth century in the United States, where a mixture was used more or less consistent by combining organized words and crime. The term criminal organization has been used more and more since the 1960s and 1970s, slowly gaining ground in the adoption of the term nationally and internationally (von Lampe, 2015).

Even more than that, one of the aspects related to the problem of defining this concept, is "the idiosyncratic use of a range of different terms such as mafia, mob, gang, syndicate, outfit, network, cell, club, cartel and so forth, which are often used to characterize organised crime" (Gottschalk, 2009).

Albanese's (2004) definition is as follows "organised crime is a continuing criminal enterprise that rationally works to profit from illicit activities that are often in great public demand. Its continuing existence is maintained through the use of force, threats, monopoly control, and/or the corruption of public officials".

According to the European Comission (Carpo, 2006), organized crime represents "a criminal organization represents a structured association, that was established over a certain period of time, of two or more individuals, acting in a concerted manner with a view to committing offenses punishable by deprivation of liberty or an order of detention for a maximum of at least four years or a more severe sentence, whether these offenses are self-inflicted or a means of obtaining material benefits and, where appropriate, of unduly influencing public authorities ". Steffeimaier (995) points out that "the world of organized crime is fluid, organizationally disordered and constantly changing, which is often ambiguous for outside observers". 
Elvins (2003) underlined the fact that, according to the EU there are a minimum of 6 characteristics (from a total of 11), regarding an entity to be defined as an organised crime entity. Of the 6 characteristics, there are 4 mandatory ones, as seen in table 1.

Table 1. Characteristics of organized crime entities

\begin{tabular}{|c|c|c|}
\hline No. & Characteristic & $\begin{array}{l}\text { Mandatory / } \\
\text { Optional }\end{array}$ \\
\hline 1. & $\begin{array}{l}\text { Collaboration between two or more people, } \\
\text { each with their on designated tasks }\end{array}$ & Mandatory \\
\hline 2. & $\begin{array}{l}\text { Developed for a long / often undetermined } \\
\text { period of time }\end{array}$ & Optional \\
\hline 3. & $\begin{array}{l}\text { Use of discipline or control in every-day } \\
\text { activity }\end{array}$ & Mandatory \\
\hline 4. & Suspect of grave criminal misconduct & Optional \\
\hline 5. & $\begin{array}{l}\text { Criminal activities undertaken at national and } \\
\text { international level }\end{array}$ & Mandatory \\
\hline 6. & $\begin{array}{l}\text { A mix of entrepreneurship and criminal } \\
\text { activities }\end{array}$ & Optional \\
\hline 7. & Use of violence and other means to intimidate & Optional \\
\hline 8. & Use of business or commercial activity & Optional \\
\hline 9. & Undertakes money laundry & Optional \\
\hline 10. & $\begin{array}{l}\text { Exercising influence over politics, the media, } \\
\text { public administration, judicial authorities, or } \\
\text { the economy }\end{array}$ & Optional \\
\hline 11. & $\begin{array}{l}\text { Determined by the pursuit of profit and / or } \\
\text { power }\end{array}$ & Mandatory \\
\hline
\end{tabular}

Source: Elvins (2003), pp. 29-41

As we can see organised crime and corruption are complicated affaires, and they become more complicated when we add the entrepreneurial or business worlds in the mixt. Because entrepreneurship and organised are linked by the desire or better said by the need of profit. The only difference is the legality of the activity.

\section{ENTREPRENEURSHIP AND ORGANISED CRIME}

There is a possibility that the use of the term organized crime may lead to the evocation of images of gangsters such as AI Capone, who are public figures, due to the wealth and power they have accumulated from the crime. Often the problem with law enforcement is not to find out who the organized criminals are, but to link them to specific crimes that can be charged. The conspiratorial and secretive nature of organized crime is what makes it serious. It is not the individual drug trafficker and the operator of illegal casinos that causes the most of public concern, but the way these individuals organize themselves, their customers, suppliers, and officials to provide illicit goods and services for profit.

Almost since the development of organised crime as an activity, there was a link between it and the business world. When we define entrepreneurs, we consider an individual who creates a new business, bearing most of the risks and enjoying most of the rewards. As well as the process of setting up a business is known as entrepreneurship (Investopedia, 2021)

Also, Smith (2010), argues that "organized crime represents a global phenomenon that is concentrated in the the development of both, personal prosperity, and a criminal culture". Probably 
the one of the most important aspects is how the enterprising community and the entrepreneurial people and the organized criminals define their own goals and identities. These individuals create a link between the legit entrepreneurial activities and the legal side of business and it leads to blurred lines between the two.

Symeonidou-Kastanidou (2007, in Gottschalk, 2009) argues that there is a need for a new definition of organised crime, where entrepreneurial structure is included as an important element. An entrepreneur is "a person who operates a new enterprise or venture and assumes some accountability for the inherent risks". The perception of the talent of entrepreneurs is that of a person who likes to take risks but is also involved in the development of a business venture. Entrepreneurship is not easy, it also tricky, because many of the new businesses are destined to fail. Such, in the case of profitbased companies, the entrepreneurs are often the same as the founders of the company. They have the strong beliefs regarding a market opportunity, and they are willing to accept a high level of personal, professional, or financial risk to pursue that opportunity.

If we consider the above presented elements, we can several important characteristics of an entrepreneur as seen by Dean et.al, (2010):

- Opportunity perspective - the entrepreneur has to develop the ability to see opportunities.

- Resources' mobilization - it is important for the entrepreneur to get an opportunity to start the business development based on the resources used to start the business.

- Decision making under uncertainty - the ability of the entrepreneur to decide in situations of uncertainty, risk, especially in situation of a business in an uncertain environment.

- People cooperation - the entrepreneur must have the ability to communicate and interact with others.

- Profit maximisation - the result of any business, be it legal or illegal must be the highest of possible profits that the entrepreneur can obtain.

Another perspective presented by Symeonidou-Kastanidou (2007), with regard to the entrepreneurial structure of an organisation must cumulate the following components:

- Allocation of roles - it happens when a group of members is exclusively tasked with planning and preparation activities, a second one is tasked with the implementation preparation activities, a second one is tasked with the implementation and execution of the plan, while a third one is responsible for securing the proceeds.

- Hierarchy - existence of a superior / inferior relationship between members of an organisation.

- Concrete structure - the existence of the organisation's own assets.

If we look at these aspects and bring to mind the entrepreneurial perspective and the criminal one, we can agree with Albanese (2004), according to whom "organised crime groups form and thrive in the same way that legitimate businesses do, they respond to the needs and de mands of suppliers, customers, regulators and competitors". The only difference between organised crime and legitimate business is that organised criminals deal in illegal products, whereas legitimate businesses generally do not. Gottschalk (2007) assumes that there is an evolutionary nature in criminal business enterprises. He considers that there is an entrepreneurial account of the nature of organized crime is inherently dynamic, in that it encourages the future to intrude on the explanation of the enterprise. The explanation of the enterprise lies not, or at least not solely, in forces that are visible today; it lies instead in how criminals organise to deal with an uncertain future.

In an entrepreneurial environment, organising the business of crime requires a market-oriented approach, where market share is important. No matter the type of business a criminal organisation is in, the market share is important to establish, sustain and increase. The main role of an entrepreneur is to develop new products and markets, to respond to consumers' needs and desires. If we take this perspective and transfer it to the concept of organised crime, we can state that the criminal markets the people or even the organisations who are willing and able to satisfy their needs. 
But at the same time, there are some issues related to the conceptual definition of criminal entrepreneurs, although, there are some authors, that mostly, in the ' 70 , ' 80 and ' 90 have tried to define criminal entrepreneurship, in relation to multiple criminal activities, like: entrepreneurship linked to prostitution (Heyl, 1978), Mafioso-entrepreneur (Hess, 1998), seeing organised crime by underlining criminal enterprise (Smith, 1975; Reuter 1983; Haller, 1990), only in the 1995, has Naylor (1995), analysed the "morphology of organized crime embodied in the Entrepreneurial Model and advocates looking beyond the relationship of organized crime to the wider economy classifying relationships of behaviour as being predatory, parasitical, and symbiotic" (Smith, 2009). Considering this, we can't clearly state that there is a clear definition of criminal entrepreneurship and also, that this idea of criminal entrepreneurship is not updated to the current conditions of the economic environment of the $21^{\text {st }}$ century.

Of course, these are just some of the issues that briefly cover the topic of organised crime and its link to the business world, and how some authors have viewed such connections in the past. While covering the issue of criminal entrepreneurship, as stated before, a missing link in the understanding of this topic came to life, that being a lack of understanding of the shifts that have occurred in the business world in the last decades, under the influence of an ever-expanding global market, that offers organised crime the opportunity to be present almost everywhere.

\section{ENTREPRENEURIAL RESULTS OF ORGANISED CRIME}

Even if this paper is mostly a literature review type of paper, we consider it important to underline several important facts related to the entrepreneurial results of organised crime. As we have stated before, there organised crime, by its illegal activities and its combination with corruption leads to grave losses for the governments and the social and economic environments.

According to the European Commission, as of April 2021, the criminal networks cover mostly the following activities: drugs; organised property crime; migrant smuggling; trafficking in human beings; cybercrime. The main purpose of infiltrating legal economy lies with the following expected results: approximately $70 \%$ use legal economy for money laundering, $60 \%$ are engaged in corruption activities; more than $80 \%$ use the cover of legal businesses. Considering the international perspective, the cross-border organised crime represents more than $65 \%$ of all entities and they all gave multiple nationalities. At the same time, considering the adaptability of the criminal activities, in the context of pandemic, these illegal organisations have tried to scam more than 1.1 billion of Covid-19 vaccine doses worth more than 15 billion euro (EU Commision, 2021).

If we consider, as an example, a United Nation Report (2010) on drug trafficking, the estimated value of the heroin and other opioids market consists of more than 15 million people, the market value represents more than 65 billion dollars a year, with more than 1 million people involved in the traffic of these drugs.

Of course, the impact of organised crime, can mostly be seen in the shadow (grey) economy of each country, not just the European Union. We know that the shadow economy, has two main components (Schneider, 2002): “(a) illegal activities - trade in stolen goods; drug dealing and manufacturing; prostitution; gambling; smuggling; fraud. (b) legal activities - unreported income from self-employment, such as salaries, and assets from unreported work related to legal services and goods", and this shadow economy's impact on the economy can be seen in the countries GDP, as seen in table 2: 
Table 2. Impact on the GDP of criminal activities - extracted countries

\begin{tabular}{|r|c|c|r|c|c|}
\hline No. & Country & \% of GDP & No. & Country & \% of GDP \\
\hline 1. & Georgia & 64.9 & 16. & Islanda & 15.8 \\
\hline 2. & Bolivia & 62.3 & 17. & Germany & 15.6 \\
\hline 3. & Zimbabwe & 60.6 & 18. & Vietnam & 15.1 \\
\hline 4. & Nigeria & 56.3 & 19. & Hong Kong & 14.7 \\
\hline 5. & Guatemala & 54.7 & 20. & Netherlands & 14.2 \\
\hline 6. & Benin & 53.7 & 21. & Australia & 14.1 \\
\hline 7. & Haiti & 53.3 & 22. & New Zeeland & 13.4 \\
\hline 8. & Gabon & 52.4 & 23. & United Kingdom & 13.3 \\
\hline 9. & Azerbaijan & 52.2 & 24. & Singapore & 11.9 \\
\hline 10. & Tanzania & 52.2 & 25. & China & 11.2 \\
\hline 11. & Myanmar & 51.4 & 26. & Japan & 10.8 \\
\hline 12. & Thailand & 50.6 & 27. & Luxembourg & 10.7 \\
\hline 13. & Gambia & 46.9 & 28. & Austria & 9.9 \\
\hline 14. & Belize & 46.8 & 29. & USA & 9.4 \\
\hline 15. & Romania & 30.2 & 30. & Switzerland & 9 \\
\hline
\end{tabular}

Source: Schneider, 2019

If we assess the above presented table, we can see that the effects of the criminal activity on the extracted countries GDP is rather important for the great majority of them. Looking at a map and comparing the data from the table and consider de economic development level and the percentages presented in table two, we can conclude that the least developed countries have the highest numbers, and the more developed countries have the lowest percentages. So based on these aspects, and on the information from the EU, we can state that the entrepreneurial result of organised crime pays of through important financial results for the illegal entities.

\section{CONCLUSIONS}

The topic of corruption and organised crime is an interesting one to study, especially from an entrepreneurial perspective, one must understand that this type of illegal activity can be also seen from a business-like point of view. Probably the most important result from such an assessment and point of view is to understand how this type of criminal activity can be fought and de-structured by the authorities. The authorities must understand that the organised crime entities are considering just some elements, like profit, power, and influence, when they consider developing and undertaking illegal activities, but at the same time they view the market from the same perspective as an entrepreneur. The entrepreneur regards the business environment form the demand and supply perspective, it has in mind the idea of satisfying the needs and desires of the consumers, and ultimately the gain of profit. The same can be said of criminal entities and their leader, just that the activities that they are involved in are of an illegal manner.

In this paper we have seen the meaning of corruption, that of organised crime and how can one identify organised crime, but also some aspects linked to entrepreneurship thinking and behaviour connected to organised crime thinking and concluding with some data regarding the impact of illegal activities on the economic and ultimately the social environment of a country. While there is no clear conclusion regrading the concept of organised crime, we can observe, that in the opinion of several important authors, there is a clear link between the illegal activity thinking and 
entrepreneurial thinking, a fact that is sustained by the figures presented above. We can also observe the fact that in some countries the impact of criminal activities is so great that it can reach more than $50 \%$ of the GDP, but also, we can see that at the EU level, more than $80 \%$ of the criminal activities are covered by legal businesses.

We acknowledge that this paper is mostly a literature review one combined with a brief secondary data analysis that sustain the theory presented but is also a starting point in the better understanding of how organised crime works and how it affects the business environment of ones' country. It also represents a starting point in future research design to understand organised crime in Romania and its impact on our economy. And while doing said research, we have observed almost a complete lack of Romanian scientific material that covers this topic, or any research undertaken by the scientific community to understand the economic implications of organised crime. Therefore, we consider that this paper can become a first stepping stone in understanding the criminal phenomena that is present in the business world.

\section{REFERENCES}

Aidis, Ruta, van Praag \& Mirjam (2004). Illegal Entrepreneurship Experience, Tinbergen Institute Discussion Paper, No. 04-105/3, Tinbergen Institute, Amsterdam and Rotterdam.

Albanese, J., S. (2004). Organised Crime in our Times, Fourth Edition, LexisNexis, Anderson Publishing, Cincinnati, $\mathrm{OH}$.

Albanese, J., S. (2010). Organised crime in our times, $6^{\text {th }}$ edition, Anderson, p.104.

Becker, G., S. (1968). Crime and punishment: An economic approach. Journal of Political Economy, 76(2), 160-217, in Scandizzo, P.L., Ventura, M. (2015), Organized crime, extortion and entrepreneurship under uncertainty. Eur J Law Econ 39, 119-144,

https://doi.org/10.1007/s10657-014-9479-3.

Béchervaise, Neil, E., Benjamin \& Colin, G. (2013). Visionary or Criminal: From Profit through Morality to Socially Sustainable Entrepreneurship, Procedia - Social and Behavioral Sciences, Volume 99, 2013, Pages 339-350.

Dean, J., Fahsing, I. \& Gottschalk, P. (2010). Organised crime, policing illegal business entrepreneurialism, Oxford university press, pp. 6-7.

Elvins, M. (2003). Europe's Response to Transnational Organized Crime, in: Edwards, A. și Gill, P. (eds.), Crime: Perspectives on Global Security, Routledge, London, pp. 29-41.

Gottschalk, P. (2009). Entrepreneurship and Organised Crime, Edward Elgar Publishing Limited, Cheltenham, UK, p. 4.

Haller, M., H. (1990). Illegal Enterprise: A Theoretical and Historical Interpretation, Criminology, Volume 28, Issue 2, pp. 207-236.

Hess, H. (1998). Mafia and Mafiosi: Origin, Power and Myth, (Edwald Osers, Trans), London, C. Hurst \& Co (publishers) ltd.

Heyl, B., S. (1979). The Madam as Entrepreneur, New Brunswick, N.J, Transaction, Routledge; 1st edition.

Jain, A., D. (2008). Corruption - a review, Journal of Economic Surveys vol. 15, no. 1, pp. 71- 121, https://doi.org/10.1111/1467-6419.00133.

Naylor, R., T. (1995). From Cold War to Crime War: The Search new National Security Threat, Transnational Organized Crime, 1, No 4, Winter 1995, in Smith, R, (2009), Understanding entrepreneurial behaviour in organized criminals, Journal of Enterprising Communities People and Places in the Global Economy, 3 (August), pp. 256-268, DOI:10.1108/17506200910982019, https://ideas.repec.org/a/eme/jecpps/v3y2009i3p256268.html, accessed on June $21^{\text {st }}, 2021$.

Reuter, P. (1983). Disorganised Crime: The Economics of the visible hand, Cambridge, M.A. 
Scandizzo, P., L. \& Ventura, M. (2015). Organized crime, extortion and entrepreneurship under uncertainty. Eur J Law Econ 39, 119-144, https://doi.org/10.1007/s10657-014-9479-3.

Schneider, F. \& Enste, D. (2002). Hiding in the shadows - the growth of the underground economy, International Monetary Fund, Economic Issues no. https://www.imf.org/external/pubs/ft/issues/issues30/\#2, accessed on June, $19^{\text {th }}, 2021$.

Smith, D., C. (1975). The Mafia Mystique, Hutchinson, London, in Smith, R, (2009), Understanding entrepreneurial behaviour in organized criminals, Journal of Enterprising Communities People and Places in the Global Economy, 3 (August), pp. 256-268, DOI:10.1108/17506200910982019, https://ideas.repec.org/a/eme/jecpps/v3y2009i3p256268.html, accessed on June $21^{\text {st }}, 2021$.

Smith, R. (2009). Understanding entrepreneurial behaviour in organized criminals, Journal of Enterprising Communities People and Places in the Global Economy, 3 (August), pp. 256-268, DOI:10.1108/17506200910982019, https://ideas.repec.org/a/eme/jecpps/v3y2009i3p256268.html, accessed on June $21^{\text {st }}, 2021$.

Steffensmeier (1995). The task force report: organized crime - Fifty years later, American Society of Criminology 73rd annual Conference Philadelphia, Pennsylvania, November 17.

Symeonidou-Kastanidou, E. (2007). Towards a new definition of organised crime in the European Union, European Journal of Crime, Criminal Law and Criminal Justice, 83-103.

Vogl, F. (1998). The supply side of global bribery. Finance and Development, 35, 2, 30 - 33.

Volintiru, C. (2014). Dimensions of corruption in Eastern and Central Europe, Democratizare și consolidare democratică în Europa Centrală și de Est, European Instituter, Iași, p. 199.

von Lampe, K. (2015). Organized Crime: Analyzing Illegal Activities, Criminal Structures, and Extra-legal Governance, Sage Publications, p. 13-15.

*** United Nations, www.unodc.org, accessed on May, 17th, 2021.

*** https://www.transparency.org/en/what-is-corruption accessed on May, 17th, 2021.

*** Modern Romanian Language Dictionary, The Romanian Academy Publishing House, Bucharest, 1958, pag.190.

*** European Union Council, Convention against corruption involving public officials, Official Journal C195, 1997.

*** Factsheet EU Strategy to tackle Organised Crime, https://ec.europa.eu/commission/presscorner/ detail/en/fs_21_1723, accessed on June 19 ${ }^{\text {th }}, 2021$.

*** Carpo, Situation Report on Organised and Economic Crime in South-eastern Europe, Carpo Regional Project, 2006.

*** https://www.investopedia.com/terms/e/entrepreneur.asp, accessed on June, 21th, 2021

*** World Drug Report, 2010, https://www.unodc.org/documents/wdr/WDR_2010/World_ Drug_Report_2010_lo-res.pdf, accessed on June, 21th, 2021. 